\title{
Keille käyttöä yleisviisaudesta?
}

Bengt Karlöf \& Fredrik Helin Lövingsson (2006). Organisaation olemus. Edita Publishing Oy. 152 sivua. ovh 58 euroa.

Ammatissani kauppatieteellisen yksikön professorina joudun lukemaan paljon erilaisia tekstejä. Toimin myös tieteellisen lehden päätoimittajana. Siinä työssä oppii nopeasti arvioimaan sekä sitä, mikä on jonkin tekstin (oletettu) yleisö, että ennen kaikkea sitä, tuntuuko teksti puhuttelevan kyseistä yleisöä.

Välillä herää kysymys, miksi joku teksti on kirjoitettu ja julkaistu. Ruotsalaisten konsulttien Bengt Karlöfin ja Fredrik Helin Lövingssonin kirjan osalta tämä kysymys tuntuu erityisen perustellulta. En pysty löytämään siihen mitään yksiselitteistä vastausta.

Karlöf ja Helin Lövingsson toteavat, että kirja on kirjoitettu etupäässä käytännön ihmisille, jotka suunnittelevat tai harkitsevat organisaationsa kehittämistä.

Maailma on täynnä erilaisia johtamisen ja organisaatioiden oppaita, ohuita ja paksuja. Kun yleisönä ovat "käytännön ihmiset”, suurin osa näistä oppaista yrittää tuoda esille jotakin uutta ja mullistavaa. Karlöf ja Helin Lövingsson tyytyvät kuitenkin listaamaan vanhaa. He tarjoavat osasia aiemmista oppaista. Konsulttien kirjoittamalta kirjalta olisin odottanut erilaista otetta: jotakin uutta pointtia tai näkökulmaa.

Johdantoluvussa kirjoittajat käyvät läpi klassisia esimerkkejä organisaatioteorioista. He esittelevät lyhyesti organisaation ja teorian käsitteitä. He näyttävät olettavan, että yritysjohtajat ovat kiinnostuneita teorioista ja nii- den sovellettavuudesta käytäntöön. Mielestäni tämä on varsin outo lähtökohta. Olen ollut siinä käsityksessä, että suurin osa johtajista ei ehdi nykyisin kaivata muuta kuin ratkaisuehdotuksia. Toivon, että olen väärässä.

Luvussa 2 esitellään erilaisia organisaatiomuotoja ja -rakenteita, "tunnetuine etuineen ja haittoineen". Kolmas luku on otsikoitu "Organisaation anatomia, fysiologia ja psykologia”. Siinä kirjoittajat puhuvat "inhimillisestä tekijästä”, vallasta, politiikasta ja kulttuureista organisaatioissa. Neljännessä luvussa käsitellään johtamista, ja suhteutetaan sitä muun muassa "työskentelyareenan” käsitteeseen. Kirjan viides luku kantaa otsikkoa "Organisointiin liittyviä näkökohtia”. Siinä puhutaan visioista, strategioista ja niiden pohjalta tehtävistä toimenpiteistä sekä pohditaan, miten saavuttaa tasapaino organisaation uudistumisen ja vakauden välille.

Kirjan kuudennessa luvussa "Välineet ja ajatusmallit" esitellään ajankohtaisiksi väitettyjä virikkeitä ja ajatusrakenteita johtamisen pohjaksi. Näitä ovat esimerkiksi arvot ja käyttäytyminen, asiakasanalyysi sekä esimerkiksi ympäristöanalyysi. Seitsemäs luku pohtii "organisaatiomuutosta askel askeleelta”.

Karlöfin ja Helin Lövingssonin kirjaa lukiessa tuntui välillä siltä, että ihailee surrealistista maalausta. Yksityiskohdat näyttävät oikeilta, mutta kokonaisuus tuntuu vieraalta - tässä tapauksessa jotenkin 1980-lukulaiselta. Tämä ei olisi ongelma sinänsä, ellei kirjan takakannessa väitettäisi, että ”olemme huomanneet, ettei niille, jotka ovat saaneet tehtäväkseen organisoida jonkin toiminnan tai osia siitä, ole juurikaan tarjolla käytännönläheisiä ohjeita”.

Ilmeisesti en kuulu Bengt Karlöfin ja Fredrik Helin Lövingssonin kirjan oletettuun yleisöön. Ehkä etsin tekstistä vääriä asioita, enkä osaa tarpeeksi arvostaa sen helppolukuisuutta.

Muuttaminen ja kehittäminen ovat kuitenkin yritystoiminnan kalutuimpia asioita. Niistä löytyy suuri määrä erilaisia käytännönläheisiä ohjeita, myös Suomeksi kirjoitettuna tai käännettynä. Ohjeita löytyy (toisten) liikkeenjohdon konsulttien tai vaikkapa organisaatiotutkijoiden kirjoista ja artikkeleista. Myös internet on täynnä tavaraa.

Jokainen muutos tai kehittämistoimenpide on monimutkainen ja ainutlaatuinen. Olen luullut, että muutosten läpivieminen ja kehittämistyö on organisaatioissa todella kellosepän tarkkaa työtä, jota ei kannattaisi lähteä tekemään yleisten "parhaiden mahdollisten tapojen” avulla, omin päin ja oman toimen ohella.

Olen ollut siinä käsityksessä, että Karlöfin ja Helin Lövingssonin kirjan kaltaisten yleishahmotusten aika olisi ohitse. Ehkä minun pitää tarkistaa kantani. Haluaisin kuitenkin tietää, kuka tällaisia kirjoja nykyisin ostaa ja miksi. 